DOI: $\square$ https://doi.org/10.15407/techned2020.04.051

\title{
USING THE CONCEPT OF POWER FACTOR FOR ESTIMATING THE DEVICES EFFICIENCY FOR CORRECTION OF NETWORKS TRANSITIONAL MODES
}

$\quad$ Journal
Publisher
ISSN
Issue
Pages

\author{
Tekhnichna elektrodynamika \\ Institute of Electrodynamics National Academy of Science of Ukraine \\ 1607-7970 (print), 2218-1903 (online) \\ No 4, 2020 (July/August) \\ $51-54$
}

\begin{abstract}
Authors
O.I. Chyzhenko, O.M. Popovych*, I.V. Trach*, O.B. Rybina Institute of Electrodynamics National Academy of Science of Ukraine, Peremohy ave., 56, Kyiv, 03057, Ukraine, e-mail: alivchizh@ukr.net, popovich1955@ukr.net, igor.trach@ied.org.ua, rybina@i.ua * ORCID ID : https://orcid.org/0000-0002-9238-5782

** ORCID ID : https://orcid.org/0000-0002-3345-2324
\end{abstract}

\begin{abstract}
The expansion of the concept of power factor, that defined for circuits with periodic voltage and currents, to three-phase circuits with asymmetric non-periodic voltage and currents is justified. It is shown that this concept is advisable both when considering transients these occur in electric networks in the start-up modes of powerful asynchronous machines, and when evaluating the effectiveness of the use of various technical devices for these modes for correcting. References 6 , figures 2 .
\end{abstract}

Key words: power factor, circuits of asymmetrical non-periodic voltages and currents, estimation of efficiency of modes correction means of electric network. 
Published: 26.06.2020

\section{References}

1. Drechsler R. Measurement and evaluation of the quality of electric power with asymmetric and non-liner load. Moskva: Energoatomizdat, 1985. 112 p. (Rus)

2. Artemenko M.Yu,, Kaplun V.V., Bobrovnyk V.M., Polishchuk S.Y. Active filters application for energy losses reduction in three-phase power supply systems. Teknichna Elektrodynamika.

2018. No 4. Pp. 53-56. DOI:

https://doi.org/10.15407/techned2018.04.053

(Ukr)

3. Atabekov G.I. Theoretical foundations of electrical engineering. Linear electrical circuits. Vol. 1. Moskva: Enerhyia, 1978. 592 p. (Rus)

4. Schrader H.J. Zur Definition der Scheinleistung in Drehstromnetzen. Zeitschrift fur Instrumentkunde

Sv. 73. Es. 11. S. 293-298 (Germ)

DOI:

https://doi.org/10.1007/BF01956001

5. Chyzhenko O.I., Rybina O.B., Trach I.V. Semiconductive regulator for managing the network modes running in direct start of the asynchronal machine of the comparable capacity. Pratsi Instytutu electrodynamiky Natsionalnoi Academii Nauk Ukrainy

. 2019. No 54. Pp.95-102. DOI:

https://doi.org/10.15407/publishing2019.54.095

(Ukr)

6 Butkevych O.F., Chyzhenko O.I., Popovych O.M., Trach I.V. An influence of the FACTS upon an electrical network's mode during direct start-up asynchronous machine in the complex load's composition. Teknichna Elektrodynamika. 2018. No 6. Pp. 62-68. DOI: https://doi.org/10.1540 7/techned2018.06.062

(Ukr)

$\underline{\text { PDF }}$ 


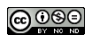

This work is licensed under a Creative Commons Attribution-NonCommercial-NoDerivatives 4.0 International License 